Modelling large-scale carbon dioxide injection into the Bunter Sandstone in the UK Southern North Sea

Proofs to be sent to: Dr D.J. Noy,

British Geological Survey, Keyworth, Nottingham, NG12 5GG, UK.

Tel: 01159363139

Fax: 01159363200

Email address: djn@bgs.ac.uk 


\title{
Modelling large-scale carbon dioxide injection into the Bunter Sandstone in the UK
}

\section{Southern North Sea}

\author{
Authors: D. J. Noy ${ }^{\mathrm{a}}$, S. Holloway ${ }^{\mathrm{a}}$, R.A. Chadwick ${ }^{\mathrm{a}}$, J.D.O. Williams ${ }^{\mathrm{a}}$, S.A. Hannis ${ }^{\mathrm{a}}$, \& R.W. Lahann ${ }^{\mathrm{b}}$ \\ Affiliations: ${ }^{a}$ British Geological Survey, Keyworth, Nottingham, NG12 5GG, UK, ${ }^{\mathrm{b}}$ GeoPressureTechnology \\ LTD, Mountjoy Research Centre, Stockton Rd, Durham, DH1 3UZ, UK.
}

Corresponding author: D.J. Noy djn@bgs.ac.uk

\begin{abstract}
The Bunter Sandstone in the UK sector of the Southern North Sea Basin is a reservoir rock that is typically 200 m or more thick and has variable but commonly fair to good porosity and permeability. East of the Dowsing Fault Zone it is folded into a number of large periclines as a result of post-depositional halokinesis in the underlying Zechstein salt. It is sealed by the overlying Haisborough Group and younger fine-grained strata and is underlain by the Bunter Shale and Zechstein Group. As such it appears to be an attractive target for industrialscale $\mathrm{CO}_{2}$ storage. However, the very large masses of $\mathrm{CO}_{2}$ that would have to be injected and stored if CCS is to be an effective greenhouse gas mitigation option are likely to cause (a) significant pore fluid pressure rise and (b) displacement of formation brines from the reservoir. A series of reservoir flow simulations of large-scale $\mathrm{CO}_{2}$ injection was carried out to investigate these effects. A simple, 3D geocellular model of the Bunter Sandstone in the NE part of the UK sector of the Southern North Sea was constructed in the Tough2 reservoir simulator in which porosity and both horizontal and vertical permeability could be varied. The injection of $\mathrm{CO}_{2}$ at various rates into the model through a variable number of wells for 50 years was simulated and the model was then run forward for up to 3000 years to see how pore fluid pressures, brine displacement and $\mathrm{CO}_{2}$ distribution evolved. The simulations suggest that provided there is good connectivity within the reservoir, and 12 optimally distributed injection locations are used, 15 - 20 million tonnes of $\mathrm{CO}_{2}$ per year could be stored in the modelled area without the reservoir pore pressure exceeding $75 \%$ of the lithostatic pressure anywhere within the model. However, significant fluxes of the native pore fluid (saline brine) to the sea occurred at a point where the Bunter Sandstone crops out at the seabed. This suggests that the potential environmental impacts of brine displacement to the sea floor should be investigated. The injected $\mathrm{CO}_{2}$ fills only up to about $1 \%$ of the total pore space within the model. This indicates that pore fluid pressure rise may be a greater constraint on $\mathrm{CO}_{2}$ storage capacity than physical containment within the storage reservoir.
\end{abstract}


Keywords: Modelling $\mathrm{CO}_{2}$ injection; flow simulation; Bunter Sandstone; Southern North Sea

\section{Introduction}

Carbon Capture and Storage (CCS) is a greenhouse gas mitigation option in which $\mathrm{CO}_{2}$ generated from large scale fossil fuel combustion, e.g. in power stations, is captured and permanently stored in geological reservoirs (IPCC, 2005). If CCS is to be adopted, very large quantities of $\mathrm{CO}_{2}$ would have to be permanently stored, even from a single power plant. A new, pulverized coal-fired, supercritical power plant with a net electrical capacity of $1 \mathrm{GW}_{\mathrm{e}}$ and $90 \% \mathrm{CO}_{2}$ capture could send about 6 million tonnes (Mt) of $\mathrm{CO}_{2}$ p.a. for storage. By comparison, a modern gas-fired power station of $1 \mathrm{GW}$ net electrical capacity with $90 \%$ capture could send around $2.5 \mathrm{Mt}$ $\mathrm{CO}_{2}$ p.a. for storage.

One of the main strategic issues for large-scale $\mathrm{CO}_{2}$ injection and storage in saline water-bearing reservoir formations is the determination of their ultimate $\mathrm{CO}_{2}$ storage capacity. This is a key parameter for policymakers because, potentially, it could determine whether or not CCS is a viable greenhouse gas mitigation option in a particular jurisdiction. Estimates of the ultimate $\mathrm{CO}_{2}$ storage capacity of a saline water-bearing reservoir need to take into account not only the pore space available for $\mathrm{CO}_{2}$ storage but also the pore fluid pressure rise induced by the displacement of in situ pore fluids by $\mathrm{CO}_{2}$ around injection wells and, for large-scale $\mathrm{CO}_{2}$ injection, more generally within the storage formation (Bachu et al., 2007; NETL, 2008; van der Meer and Egberts, 2008). When large-scale $\mathrm{CO}_{2}$ injection takes place, the reservoir rock's native pore fluids will be compressed and/or mobilised. Mobilisation of the native pore fluids could result in migration of pore fluid to the ground surface or seabed through onshore or seabed outcrops of the reservoir formation. Alternatively the displaced fluids could move into adjacent formations, which will become overpressured and their native pore fluids may in turn be displaced. Direct displacement of (potentially highly saline) brines to the water table/ground surface or seabed could have ecological impacts, which would need to be assessed on a case-by-case basis. These potential dynamic effects are investigated below, using the Tough2 reservoir simulator (Pruess et al., 1999; Pruess, 2005) to model large-scale $\mathrm{CO}_{2}$ injection into a simple model of the Bunter Sandstone Formation in the NW part of the UKSNS.

\section{The Bunter Sandstone}


The Bunter Sandstone is the offshore part of a major sandstone reservoir rock unit that onshore in Eastern England is known as the Sherwood Sandstone Group. Figure 1 shows the outcrop and subsurface distribution of this rock unit, and eight gas fields that have Bunter Sandstone reservoirs. The Dowsing Fault Zone and Central Fracture Zone (Cameron et al., 1992) separate the shallower Eastern England Shelf from the deeper basin to the east. In the latter area, depth to top Bunter Sandstone is locally quite variable because of the effects of salt movement in the underlying Zechstein Group, but typically it is between 1000 and $3000 \mathrm{~m}$. The formation thickness gradually reduces to zero on its northern margin, likely as a result of erosion beneath the Hardegsen disconformity (Geluk and Röhling, 1997). North of this pinchout, the Bunter Shale Formation and the Haisborough Group, which respectively underlie and overlie the Bunter Sandstone to the south, become indistinguishable and in this area are described as a single lithostratigraphic unit, the Smith Bank Formation. To the NE the Bunter Sandstone extends into the Dutch sector. Around the Cleaver Bank High and on the northern margin of the London-Brabant Massif, the margin is also erosional and lies beneath the Late Cimmerian unconformity, as, for example, in the Orwell field, where a Bunter Sandstone gas reservoir lies directly beneath a Speeton Clay seal.

[Figure 1 about here]

Periclinal folds within the Bunter Sandstone (Figure 2) were formed by the development of salt pillows and domes in the underlying Zechstein Group (e.g. Taylor, 1986; Underhill, 2009). Some of these periclines contain gas fields (Bifani 1986; Ritchie and Pratsides 1993) but others are not gas-bearing. At least some of the gasbearing domes are not full to spill point. This has been ascribed to a lack of migration paths from the underlying Carboniferous source rocks (Fisher, 1986), or in some cases possibly to a post-gas charge increase in the size of the closure containing the gas field as a result of subsequent halokinesis (Ketter, 1991), rather than leakage through the cap rock, perhaps because these domes appear to be unfaulted (Ketter, 1991; Ritchie and Pratsides, 1993). Some of the non-gas-bearing periclines are clearly cut by extensional faults which reach from the seabed to the Bunter Sandstone reservoir. In others, the Bunter Sandstone does not appear to be intersected by seismically resolved faults, though faults that terminate above the reservoir may be present in the overlying succession (Figure 2). In the absence of a gas accumulation it is difficult to conclusively demonstrate the structural integrity of the individual non-gas-bearing domes and thus their ability to reservoir significant columns of $\mathrm{CO}_{2}$. We consider this to be the key remaining uncertainty in their $\mathrm{CO}_{2}$ storage prospectivity. 
[Figure 2 about here]

\subsection{Depositional environment}

In the Esmond, Forbes and Gordon gas field complex, the Bunter Sandstone is thought to have been deposited within an arid to semi-arid fluvial environment consisting of alluvial fans dissected by braided fluvial channels (Bifani, 1986). In the area around the Caister B gas field, sediment is derived from the west-southwest, and is thought to drain into a playa lake to the north and northeast of the field via a series of low sinuosity channels, transecting a low relief alluvial braidplain (Ritchie and Pratsides, 1993). Halite and anhydrite cements are common within the Bunter Sandstone Formation, with varying quantities observed within individual fields (Ketter, 1991). In the area modelled, rapid lateral and vertical variations in grain size, lithology and degree and nature of cementation result in reservoir property distributions that are difficult to predict.

\subsection{Porosity and permeability}

Porosity and permeability are highly variable (Tables 1, 2; Figure 3). Porosity values show significant scatter around an arithmetic mean value of 19\%, with a tendency for greater scatter towards the lower end of the range (Figure 3a, b). From this regional core data, no discernible correlation exists between current depth and porosity. A clearer linear relationship exists between horizontal and vertical permeabilities at the higher end of the permeability range (Figure 3c). Table 1 and Figure 3 show the average vertical permeabilities are typically some $30 \%$ lower than the horizontal permeabilities.

[Tables 1 and 2, Figure 3 about here]

\subsection{Pore fluids}

In those parts of the UKSNS where hydrocarbons are absent, the open pore space is filled with highly saline brine (Table 3).

[Table 3 about here] 
The Bunter Sandstone is normally (hydrostatically) pressured. In the Hewett field, to the south of the modelled area, the brine pore fluid pressure gradient is $10.4 \mathrm{KPa} / \mathrm{m}(0.46 \mathrm{psi} / \mathrm{ft})($ Cooke-Yarborough and Smith, 2003) which implies a pore fluid density of $1.06 \mathrm{~g} \mathrm{~cm}^{-3}$. Given the reported in-situ temperature of $42^{\circ} \mathrm{C}$ and pressure of 9.39 $\mathrm{MPa}$ at $884 \mathrm{~m}$ this density is obtained at a salinity of about 100,240 ppm using subroutines from TOUGH2 (Pruess, 2005).

\subsection{Compartmentalisation}

Structural compartmentalisation, particularly the size of reservoir compartments, is a key parameter for $\mathrm{CO}_{2}$ storage in saline water-bearing reservoir rocks. The combination of the effective pore volume of the compartment, the permeability of the compartment boundaries and rock/fluid compressibilities determines the amount of $\mathrm{CO}_{2}$ that can be injected into a reservoir compartment before a particular limiting pore fluid pressure is reached. There is little published evidence as to the extent of compartmentalisation within the Bunter Sandstone in the UKSNS. However, it is known that there is pressure communication between the Hewett gas field and the adjacent Little Dotty gas field (Cooke-Yarborough and Smith, 2003) even though the crests of these fields are approximately $5 \mathrm{~km}$ apart and they are separated by the North Hewett Fault. Thus, in this area at least, there are grounds to believe that the displacement of brine through the pore space would not be significantly inhibited by flow compartmentalisation by faults juxtaposing sand against sand.

\subsection{Cementation as a pressure communication inhibitor}

In the NE of the UKSNS, pore-filling halite cement forms a permeability barrier or at least a significant permeability baffle immediately below the gas-water contact in the Bunter Sandstone of the Caister B field (Ritchie and Pratsides, 1993). This suggests that the cement was deposited post-gas charge. Halite cement is also present in the Esmond, Forbes and Gordon fields (Bifani, 1986). Here it appears to be patchily distributed, occurring mainly in the coarser-grained sandstones but, where present, it can completely occlude porosity. All these gas fields are within the modelled area. It seems possible therefore that patchily distributed halite cement might adversely affect permeability and pressure communication in the Bunter Sandstone in large parts, if not all, of the modelled area. 


\subsection{Overlying and underlying formations}

The Bunter Sandstone is sealed above by the mudstones and evaporites of the Upper Triassic Haisborough Group (Cameron et al., 1992), which forms a thick and laterally continuous succession of predominantly red mudstones. It includes three major halite members that are widely distributed but not ubiquitous throughout the SNS and appears to have excellent seal potential (Holloway et al., 2006), sealing the Bunter Sandstone gas reservoirs in the Esmond, Forbes, Gordon, Hewett, Little Dotty, Caister B and Hunter fields (Fig. 1). The typical succession in the NW part of the UKSNS (Figure 4) includes the Rot Halite Member, which is up to about $70 \mathrm{~m}$ thick hereabouts and probably enhances the seal quality of the Haisborough Group.

The Bunter Shale (Figure 4) underlies the Bunter Sandstone. It forms an effective seal to the Hewett Sandstone Member (also known as the Lower Bunter Sandstone) gas reservoir in the Hewett field in the SW of the UKSNS (Cooke-Yarborough and Smith, 2003).

[Figure 4 about here]

\section{Geological model of the Bunter Sandstone}

A simplified 3D static geological model of part of the Bunter Sandstone in the NE of the UKSNS was built from isopach and depth maps (Figure 5). The model spans some $130 \mathrm{~km} \mathrm{E-W}$ by $116 \mathrm{~km} \mathrm{~N}-\mathrm{S}$ and uses a grid of $152 \mathrm{x}$ $131 \times 15$ elements, sized $800 \mathrm{~m} \times 800 \mathrm{~m}$ over the central portion and expanding to $2 \mathrm{~km} \times 2 \mathrm{~km}$ near the boundaries. Element thicknesses vary from $1 \mathrm{~m}$ in the NE, where the formation is thinning out, to just over $37 \mathrm{~m}$ in the south, where the formation is thickest (up to $376 \mathrm{~m}$ ). Five reference observation points were located within the model at which pressure and $\mathrm{CO}_{2}$ saturations are reported. The first coincides with the injection point and the rest are spaced at roughly $6 \mathrm{~km}$ intervals along a profile to the NW (Figure 5).

The outer boundary of the model roughly corresponds to a series of discontinuous salt walls that cut through the entire Bunter Sandstone to the south and east, the stratigraphical limit of the Bunter Sandstone to the north and east, a zone of major faults (the Dowsing Fault Zone) to the west and an un-named zone of faults to the northwest. Parts of the boundary (the erosional margins and the salt walls) are thought to be essentially impermeable. It is also thought possible that the larger faults in the Dowsing Fault Zone could juxtapose the 
Bunter Sandstone against underlying mudstones and, even if this is not the case, diagenesis around the faults might significantly impede fluid flow across them. However, it seems likely that the lateral boundary with the Netherlands sector is open both north and south of the Cleaver Bank High. From a pore fluid pressure rise perspective conservatively, and for simplicity, the model's lateral boundary was modelled as a no-flow closed boundary in all of the simulations, because most of it is considered likely to prevent or significantly impede fluid flow. This boundary encloses 193125 elements of the mesh as shown in Figure 5 and all models were calculated on this subset of the full mesh. The reservoir does not contain any permeability barriers within the model boundary because it is assumed that even if the smaller faults that do not form part of continuous fault zones are in fact impermeable, on the basin-wide scale of the modelling, fluids will move around them. Potential low permeability zones formed by the occlusion of porosity by halite cement have not been modelled.

The seal above the reservoir is the Haisborough Group and overlying fine-grained Jurassic and Early Cretaceous rocks. It was estimated that the permeability of structurally sound Haisborough Group strata would not be greater than about $10^{-19} \mathrm{~m}^{2}$. For example, Harrington et al. (2009) obtained values of around $4 \times 10^{-19} \mathrm{~m}^{2}$ from samples of Nordland shale, whilst Neuzil $(1993,2000)$ reports permeabilities of $10^{-20} \mathrm{~m}^{2}$ or less for Pierre Shales. Consequently the overburden was assigned a permeability of $10^{-19} \mathrm{~m}^{2}$ in most of the dynamic modelling runs. However there is a possibility that the Haisborough Group and overlying fine-grained strata might be fractured over the crests of salt domes due to folding of the reservoir and cap rock during the halokinesis that formed the domes (there is seismic evidence of faulting at the crests of some of the domes). Consequently, in the dynamic modelling, a variation on the base case simulation was undertaken using a higher cap rock permeability (of $10^{-17} \mathrm{~m}^{2}$ ) to notionally simulate the possibility of low flux migration through the cap rock via fractures.

The Bunter Shale underlies the reservoir throughout the modelled area and for dynamic modelling purposes was assumed to be impermeable.

The Bunter Sandstone is thought to crop out at the seabed in the area immediately around well 43/28a-3, which is drilled on the top of a salt dome within the modelled area (Figure 5). The first cuttings returned from this well, from a depth of $76 \mathrm{~m}$ below seabed, are of orange-red sandstone (i.e. Bunter Sandstone). Base Bunter Sandstone is placed at $298 \mathrm{~m}$ below sea bed. The thickness of the complete Bunter Sandstone succession in the two nearest 
wells is 287 and $294 \mathrm{~m}$, suggesting that the Bunter Sandstone is likely to crop out at the seabed or beneath a veneer of drift. An outcrop with an area of $7.68 \mathrm{~km}^{2}$ (12 grid blocks) has been included in the model at this point (henceforth described as the seabed outcrop).

[Figure 5 about here]

\section{Pressure control considerations for the dynamic modelling}

A set of Leak-Off Test (LOT, squares) and formation fluid pressure data (triangles) for the Southern North Sea are displayed in Figure 6 relative to sea floor, a hydrostatic pressure gradient of $10.07 \mathrm{MPa} / \mathrm{km}$ (blue line) and a lithostatic pressure gradient of $22.5 \mathrm{MPa} / \mathrm{km}$ (red line).

[Figure 6 about here]

The LOT and formation fluid pressures are adjusted to a sea floor depth and pressure reference. No data from depths greater than $3000 \mathrm{~m}$ are displayed as $3000 \mathrm{~m}$ is assumed to be the maximum depth appropriate for the Bunter Sandstone Formation in the study area.

The black line on Figure 6 represents a pressure gradient of $75 \%$ of the lithostatic pressure. This value approximates the lower bound of the reported LOTs at depths greater than 1000 meters. At depths shallower than 1000 meters on Figure 6, the light blue line indicates a trend of $75 \%$ of a lithostatic pressure gradient of 21.5 MPa/km. This trend is an appropriate limit to the observed LOT values between seabed and 1000 metres, although a number of measurements are reported at lower pressures. Some of the relatively low LOT measurements may not have been taken to full leak-off and are correspondingly low relative to other measurements at the same depth. Lithostatic gradients commonly increase with depth due to the occurrence (with depth) of increasingly dense sediments. A constant ratio of LOT to lithostatic pressure of 0.75 , combined with an increasing lithostatic gradient ranging from $21.5 \mathrm{MPa}$ at sea floor to $22.5 \mathrm{MPa} / \mathrm{km}$ at $1000 \mathrm{~m}$ would provide a continuous minimum LOT value trend from seafloor to 3000 meters. Consequently, in terms of pressure control, our base assumption is that geomechanical stability of the reservoir would be maintained provided that pressures remain below $75 \%$ of lithostatic at any point within the model. For simplicity, a lithostatic pressure gradient of $22.5 \mathrm{MPa} / \mathrm{km}$ was assumed in the dynamic modelling. 


\section{Dynamic modelling of $\mathrm{CO}_{2}$ injection into the Bunter Sandstone}

Flow simulations were run to simulate the effects of large-scale $\mathrm{CO}_{2}$ injection into the Bunter Sandstone for a range of reservoir properties. In all simulations each injection point consists of a vertically stacked set of single cells that comprise the entire thickness of the Bunter Sandstone. $\mathrm{CO}_{2}$ was injected through these sets of cells at a constant annual rate for 50 years. The model was then allowed to run forward for a further 950 years (1000 years from the start of injection). Dissolution of $\mathrm{CO}_{2}$ in the formation pore-water is included in the model.

\subsection{The base case simulation}

A base-case model was run using the parameters listed in Table 4. The modelled injection point lies at a depth of $1552 \mathrm{~m}$ and the initial formation pressure at the top of the reservoir at the injection point in the model is 16.7 $\mathrm{MPa}$ (based on a pressure gradient of $10.67 \mathrm{KPa} / \mathrm{m}$ derived from a salt mass fraction of 0.13 and a temperature gradient of $35^{\circ} \mathrm{C} / \mathrm{km}$ ): the geothermal gradient actually varies between $\approx 30$ to $\approx 35^{\circ} \mathrm{C} / \mathrm{km}$ across the modelled area (Oxburgh and Andrews-Speed, 1981). A corresponding lithostatic pressure of $34.92 \mathrm{MPa}$ was based on a lithostatic pressure gradient of $22.5 \mathrm{KPa} / \mathrm{m}$. A pore compressibility value of $4.5 \times 10^{-10} \mathrm{~Pa}^{-1}$ was chosen to be representative of structurally sound sandstone (Zhou et al., 2007) in the absence of specific data. Brine compressibility is not specified explicitly in TOUGH2 input but is determined implicitly by the code through its functional dependence of density on pressure, temperature, and salinity (Pruess, 2005). The injection rate was 5 x $10^{6}$ tonnes $\mathrm{CO}_{2}$ per annum $\left(158.4 \mathrm{~kg} \mathrm{~s}^{-1}\right) \cdot \mathrm{CO}_{2} /$ brine relative permeability curves derived from the Sleipner $\mathrm{CO}_{2}$ storage reservoir - the Utsira Sand - were used in the base case simulation (Erik Lindeberg pers. comm.). The curves are plotted in Figure 10d.

[Table 4 about here]

The base-case simulation shows that, apart from at the injection point, maximum pore fluid pressures are produced after 50 years, immediately prior to cessation of injection (Figure 7). Pressure at 50 years does not exceed $75 \%$ of the modelled lithostatic pressure anywhere within the model.

[Figure 7 about here] 
Note that the localised initial high pressure transient at the injection well could be avoided by building up the injection rate slowly, and/or utilising multiple injection wells. In any case it naturally decreases during the injection period as the relative permeability to $\mathrm{CO}_{2}$ increases (Chadwick et al., 2009). At the end of the injection period there is a rapid pressure fall-off near the injection point as the pressure equilibrates within the model as a whole and a longer term decline due to water leaving the system via the seabed outcrop and the low permeability caprock. Longer term residual excess pressures are less than $0.5 \mathrm{MPa}$ and are partly due to the buoyancy effect of the trapped $\mathrm{CO}_{2}$ plume. If a suitable injection strategy could be adopted to reduce the initial pressure transient at the injection point, running the base-case model produces an acceptable pressure build-up after the injection of $250 \mathrm{Mt} \mathrm{CO}_{2}$ through a single well over a 50 year period.

Figure 7 also shows the distribution of free $\mathrm{CO}_{2}$ at the end of the injection phase (50 years) and after 3000 years. It can be seen that $\mathrm{CO}_{2}$ spread is dominantly radial during the injection phase, driven by the injection point overpressure. Post-injection migration is dominated by buoyancy (gravity forces) and the $\mathrm{CO}_{2}$ migrates updip towards the nearby topographic high point in the overburden surface.

Reservoir pressure changes at the observation points and the flux of pore fluid from the seabed outcrop are also shown in Figure 7. The modelling suggests that over a protracted period (several hundred years) some $360 \mathrm{Mt}$ of pore water will emerge through the seafloor at the seabed outcrop, with flux rates peaking at $>75 \mathrm{~kg} / \mathrm{s}(6514$ tonnes/day). The effect of this is to significantly reduce pressure buildup in the reservoir. The pressure reduction attributable to brine flux at the seabed outcrop can be estimated by comparing the pressure distribution as a percentage of the lithostatic pressure in the base case model with a model in which the Bunter Sandstone is assumed to be at a depth of $325 \mathrm{~m}$ at the location of the seabed outcrop, i.e. without the seabed outcrop (Figure 8).

[Figure 8 about here]

\subsection{Sensitivity to overburden permeability.}

It was noted above that the permeability of the overburden might be significantly increased by the presence of pre-existing faults or fractures, particularly over the crests of salt domes. To test the impact of increased permeability in the caprock a variation of the base case model was run with the overburden permeability raised 
to $10^{-17} \mathrm{~m}^{2}$. Figure 9 shows that the pressure footprint is substantially reduced in comparison to the base case in Figure 7. The flow of brine from the seabed outcrop is also reduced, both in flow rate which peaks at $35.4 \mathrm{~kg} \mathrm{~s}^{-1}$ and in the total cumulative flow which is restricted to $90 \mathrm{Mt}$ over several hundred years.

[Figure 9 about here]

\subsection{Sensitivity to relative permeability}

In order to test the sensitivity of the results to different $\mathrm{CO}_{2}$-brine relative permeability curves, the base case model was then run with relative permeability curves that were fitted to the Cardium Sandstone data for $\mathrm{IFT}=19.8 \mathrm{mN} / \mathrm{m}$ (Bennion and Bachu, 2006). As shown in Figure 10d, these curves have a higher residual water saturation than the base case curves from the Utsira Sandstone, but otherwise have greater relative permeability for both water and $\mathrm{CO}_{2}$ at other saturations. The simulation had to be terminated at 60 years due to problems with the timestep convergence in Tough2 (Figure 10). There is a slight increase in the area of the $\mathrm{CO}_{2}$ distribution caused by the higher irreducible water saturation, but pressure increase and brine flux rates are virtually indistinguishable from those modelled with the Sleipner relative permeability curves. It may be noted that the relative permeabilities are represented by simple curves rather than by separate drainage and imbibition curves as TOUGH2 does not incorporate hysteretic effects. It is expected that any effects of differing imbition curves would be relatively minor and only affect the migration of the plume after injection has ceased. Peak pressures through the reservoir at the end of injection are not expected to be affected.

[Figure 10 about here]

\subsection{Effect of reducing reservoir permeability}

Figure 11 shows the effect of reducing the permeability of the base-case model to $20 \mathrm{mD}$. Reservoir pressure exceeds $75 \%$ of the lithostatic pressure around the injection point indicating that an injection rate of $5 \times 10^{6}$ tonnes/year through a single injection point is too high at this permeability. As would be expected, the migration of the $\mathrm{CO}_{2}$ plume is much slower and the rate of brine flux to the seabed is reduced with the peak rate down to $21 \mathrm{~kg} \mathrm{~s}^{-1}$ and the total flow reaching only $277 \mathrm{Mt}$ by 3000 years. 


\subsection{Injection through multiple injection points}

A model with twelve injection points, each injecting 1 million tonnes of $\mathrm{CO}_{2}$ per year $\left(31.7 \mathrm{~kg} \mathrm{~s}^{-1}\right)$, was developed in order to investigate the storage capacity and brine flux with injection through multiple wells. There is no particular significance in the location of the injection points, but they are typically separated by about 15$20 \mathrm{~km}$ and placed close to local structural highs in the top surface of the Bunter Sandstone (Figure 12).

Figure 12 shows that the pressure increases are distributed broadly throughout the reservoir with localised highs only apparent around the injection points to the northeast where the formation is thinnest. The plot of pressure as a percentage of the lithostatic pressure shows that this remains below $75 \%$. Some of the topographic highs to the southeast of the modelled zone reach about $70 \%$ of lithostatic pressure. The flow rate of brine from the seabed outcrop peaks at $170 \mathrm{~kg} / \mathrm{s}$ with a total of $840 \mathrm{Mt}$ of brine displaced over 1500 years.

[Figure 12 about here]

\subsection{Optimising the injection rate through 12 wells}

Further simulation runs were undertaken, varying the injection rate at the 12 injection points, in order to maximise the mass of $\mathrm{CO}_{2}$ injected whilst keeping reservoir pressures below the $75 \%$ of lithostatic threshold. This can be achieved for total injection rates of $21.9 \mathrm{Mt} / \mathrm{yr}\left(694 \mathrm{~kg} \cdot \mathrm{s}^{-1}\right)$ when $\mathrm{k}=100 \mathrm{mD}$ and $13.7 \mathrm{Mt} / \mathrm{yr}(434$ $\mathrm{kg} \cdot \mathrm{s}^{-1}$ ) when $\mathrm{k}=20 \mathrm{mD}$ (Figure 13). Brine fluxes at the seabed outcrop peak at $291 \mathrm{~kg} \cdot \mathrm{s}^{-1}$ and $49.2 \mathrm{~kg} \cdot \mathrm{s}^{-1}$ respectively. It was not possible to progress the $100 \mathrm{mD}$ simulation beyond 150 years due to timestep convergence problems with TOUGH2, but by this time 833 Mt of brine had flowed from the seabed outcrop, which is estimated to be about half of the long term total. The $20 \mathrm{mD}$ run had generated $723 \mathrm{Mt}$ of displaced brine after 3000 years.

It is noted that with a reservoir permeability of $20 \mathrm{mD}$ it is the pressure around the injection points that limits the overall injection rate. In contrast, with a reservoir permeability of $100 \mathrm{mD}$, the maximum injection rate is limited by pressure increases at a few locations near the southern boundary of the model where the top of the reservoir rises to depths of less than $1000 \mathrm{~m}$. At these points relatively small pore pressure increases can give 
rise to a breach of the $75 \%$ of lithostatic pressure limit. It is worth stressing though, that if induced fracturing were to occur, only brine would be displaced from the reservoir (Smith et al., 2010).

[Figure 13 about here]

\section{Discussion}

The modelling provides only a very simplified representation of the NW part of the Bunter Sandstone Formation in the UKSNS. In particular, the model does not include reservoir heterogeneity. Moreover, the reservoir pressure observed in the simulations is likely to be sensitive to the model's lateral boundary conditions, being significantly lower if the model's lateral boundary conditions are fully or partially open (Smith et al. 2010). Nevertheless it is clear that pore fluid pressure rise could be a significant issue at a considerable distance outside the $\mathrm{CO}_{2}$ footprint at the end of the injection period, particularly where the reservoir is at shallow depths.

The results of the modelling give a very broad indication of the scale of $\mathrm{CO}_{2}$ injection that could be possible and the strategy that might be employed to maximise storage whilst not exceeding a limiting pore fluid pressure increase. With 12 injection points, approximately $14-22 \mathrm{Mt} \mathrm{CO}_{2}$ per year can be injected into the model for 50 years without exceeding $75 \%$ of the lithostatic pressure anywhere within the model $\left(0.75-1.0 \times 10^{9}\right.$ tonnes in total) when the formation permeability is set to $20 \mathrm{mD}$ and $100 \mathrm{mD}$ respectively. The results assume that pressure management wells are not used. Pressure management wells could at alleviate reservoir pressure buildup and thus allow more $\mathrm{CO}_{2}$ to be injected.

The peak modelled flux of pore water at the seabed outcrop (after 50 years) ranges between 49 and $290 \mathrm{~kg} / \mathrm{s}$ (which corresponds to between 1.4 and $8.5 \times 10^{6} \mathrm{~m}^{3}$ per year given the brine density of $1.075 \mathrm{~g} / \mathrm{cm}^{3}$ ). The total volume of pore fluid emerging through the seabed outcrop during and after the injection period ranges between $670 \times 10^{6}$ and $775 \times 10^{6} \mathrm{~m}^{3}$, although the latter figure is from an incomplete simulation and the final figure would be expected to be about $1500 \times 10^{6} \mathrm{~m}^{3}$.

There is likely to be a salinity gradient between the pore water in the Bunter Sandstone near the seabed and the high salinity brine at depth. Thus initially at least, relatively low salinity pore water may be emitted. Nevertheless, the potential ecological implications should be assessed. Thought could also be given to 
techniques that could be used to monitor the flux and salinity of brine migration to the sea floor as a result of large scale $\mathrm{CO}_{2}$ injection offshore, should this prove necessary. On the other hand, we have not included flow barriers within the reservoir. If present, these would have two effects: to increase pressures generally around the injection points and to reduce brine displacement at the seabed.

In most of the simulations reported here the total volume of brine expelled from the seabed outcrop of the Bunter Sandstone is only slightly less than the final volume of the injected $\mathrm{CO}_{2}$. The exception, apart from the incomplete simulations, is the case in which the overburden permeability is increased and the total brine volume expelled from the seabed outcrop is reduced by $75 \%$. The remainder of the pressure relief in this case comes from the dispersed migration of brine through the overburden at very low rates but over a large area. This feature, together with the reduced extent of the pressure increases about the injection points could potentially permit the injection of greater volumes of $\mathrm{CO}_{2}$ if the regional scale permeability of the overburden is greater than the value of $10^{-19} \mathrm{~m}^{2}$ assumed in the majority of these simulations. The volume of brine expelled from the seabed outcrop is likely to be sensitive to the model's lateral boundary conditions as well as the overburden permeability and would be expected to be lower than in our simulations if the lateral boundaries of all or parts of the area modelled are open rather than closed.

In all the simulations presented here, pressures at the injection point reach high values at early times in the injection period. This is primarily due to the use of a simple step function for the injection history. In practice, suitable injection strategies, involving multiple wells and carefully controlled injection ramping would need to be deployed to control near-wellbore pressure.

Although the models used in this study have a very simplified representation of the storage reservoir, the injected $\mathrm{CO}_{2}$ fills only a very small portion of the available pore-space (a maximum of about $1 \%$ in the cases considered here). This indicates that pore fluid pressure rise may be a greater constraint on $\mathrm{CO}_{2}$ storage capacity than physical containment within the storage formation.

\section{Acknowledgements}

The authors would like to thank IHS for permission to show pressure-related information from the Southern North Sea and David Hughes for much useful discussion of the Bunter Sandstone as a potential reservoir. This 
publication has been produced with support from the BIGCCS Centre. The BIGCCS Centre is part of the Norwegian research programme Centres for Environment-friendly Energy Research (FME) and is funded by the following partners: Aker Solutions, ConocoPhillips, Det Norske Veritas, Gassco, Hydro, Shell, Statoil, TOTAL, GDF SUEZ and the Research Council of Norway (193816/S60). The BGS authors publish with the permission of the Executive Director, British Geological Survey (NERC).

\section{References}

Bachu, S., Bonijoly, D., Bradshaw, J., Burruss, R., Holloway, S., Christensen, N-P., Mathiassen, O-M., 2007. $\mathrm{CO}_{2}$ storage capacity estimation: Methodology and gaps. International Journal of Greenhouse Gas Control, 1, 430-443.

Bennion, D.B., Bachu, S., 2006. Dependence on Temperature, Pressure and Salinity of the IFT and Relative Permeability Displacement Characteristics of $\mathrm{CO}_{2}$ Injected in Deep Saline Aquifers. SPE 102138, Society of Petroleum Engineers.

Bifani, R., 1986. Esmond Gas Complex, in: Brooks, J., Goff, J.C. \& van Hoorn, B (Eds.), Habitat of Palaeozoic Gas in N.W. Europe, Geological Society Special Publication No. 23, 209-221.

Cameron, T. D. J., Crosby, A., Balson, P. S., Jeffery, D. H., Lott, G. K., Bulat, J., Harrison, D. J. 1992. United Kingdom offshore regional report: the geology of the southern North Sea. London, HMSO for the British Geological Survey.

Chadwick, R.A., Noy, D.J., Holloway, S., 2009. Flow processes and pressure evolution in aquifers during the injection of supercritical $\mathrm{CO}_{2}$ as a greenhouse gas mitigation measure. Petroleum Geoscience. 15, 59-73.

Cooke-Yarborough, P., Smith, E., 2003. The Hewett fields: Blocks 48/28a, 48/29, 48/30, 52/4a, 52/5a, UK North Sea: Hewitt, Big Dotty, Little Dotty, Della, Dawn and Delilah fields, in: Gluyas, J.G., Hichens, H.M. (Eds.), United Kingdom Oil and Gas Fields, Commemorative Millenium Volume, Geological Society (London) Memoir 20, 731- 740. 
Fisher, M.J., 1986. Triassic, in: Glennie, K.W. (Ed.). Introduction to the Petroleum Geology of the North Sea.

Blackwell Scientific Publications, Oxford, pp. 113-132.

Geluk, M.C., Röhling, H.-G, 1997. High-resolution sequence stratigraphy of the Lower Triassic 'Buntsandstein' in the Netherlands and northwestern Germany. Geologie en Mijnbouw 76, 227-246.

Harrington, J. F., Noy, D.J., Horseman, S.T., Birchall, D.J., Chadwick, R.A., 2009. Laboratory study of gas and water flow in the Nordland Shale, Sleipner, North Sea, in: Grobe, M., Pashin, J.C., Dodge, R.L. (Eds.), Carbon dioxide sequestration in geological media - State of the science: AAPG Studies in Geology 59, 521- 543.

Holloway, S., Vincent, C.J., Bentham, M.S., Kirk, K.L., 2006. Top-down and bottom-up estimates of $\mathrm{CO}_{2}$ storage capacity in the UK sector of the Southern North Sea Basin. Environmental Geoscience, 13, 74-81.

IPCC, 2005. IPCC Special Report on Carbon Dioxide Capture and Storage. Prepared by Working Group III of the Intergovernmental Panel on Climate Change [Metz, B., O. Davidson, H. C. de Coninck, M. Loos, and L. A. Meyer (eds.)]. Cambridge University Press, Cambridge, United Kingdom and New York, NY, USA, 442 pp.

Ketter, F.J., 1991. The Esmond, Forbes and Gordon Fields, Block 43/8a, 43/13a, 43/15a, 43/20a, UK North Sea, in, Abbotts, I.L. (Ed.), United Kingdom Oil and Gas fields, 25 Years Commemorative Volume, Geological Society (London) Memoir 14, 425-432.

Neuzil, C.E., 1993. Low fluid pressure within the Pierre Shale: a transient response to erosion. Water Resources Research, 29, 2007-2020.

Neuzil, C.E., 2000. Osmotic generation of 'anomalous' fluid pressures in geological environments. Nature, 403, $182-184$.

NETL, 2008. Carbon Sequestration Atlas of the United States and Canada, $2^{\text {nd }}$ Edition. U.S. Department of Energy Office of Fossil Energy National Energy Technology Laboratory. 
Oxburgh, E.R., Andrews-Speed, C.P., 1981. Temperature, Thermal Gradients and Heat Flow in the Southwestern North Sea, in: Petroleum Geology of the Continental Shelf of North-West Europe, Institute of Petroleum, London, pp. 141-151.

Pruess, K., 2005. ECO2N: A TOUGH2 Fluid Property Module for Mixtures of Water, NaCl, and $\mathrm{CO}_{2}$. Lawrence Berkeley National Laboratory Report LBNL-57952.

Pruess, K., Oldenburg, C., Moridis, G., 1999. TOUGH2 User's Guide, Version 2.0. Lawrence Berkeley National Laboratory Report LBNL-43134.

Ritchie, J.S., Pratsides, P. 1993. The Caister fields, Block 44/23a, UK North Sea, in: J.R. Parker (Ed.), Petroleum Geology of Northwest Europe: Proceedings of the Fourth Conference, Geological Society, London, 759-769.

Smith, D.J., Noy, D.J., Chadwick, R.A., Holloway, S. 2011. The impact of boundary conditions on $\mathrm{CO}_{2}$ storage capacity estimation in aquifers. Energy Procedia 4 (2011), 4828-4834. Elsevier.

Taylor, J.C.M. 1986. Late Permian-Zechstein, in: Glennie, K.W. (Ed.). Introduction to the Petroleum Geology of the North Sea. Blackwell Scientific Publications, Oxford, pp. 87-111.

Underhill, J.R., 2009. Role of intrusion-induced salt mobility in comtrolling the formation of the enigmatic ‘Silverpit Crater', UK Southern North Sea. Petroleum Geoscience 15, 197-216.

Van der Meer, L.G.H., Egberts, P.J.P., 2008. A General Method for Calculating Subsurface $\mathrm{CO}_{2}$ Storage Capacity. OTC 19309. Offshore Technology Conference, Houston, Texas, USA, 5-8 May 2008.

Warren, E.A., Smalley, P.C., 1994. North Sea Formation Waters Atlas. Geological Society (London), Memoir 15. 
Zhou, Q., Birkholzer, J.T., Rutqvist, J., Tsang, C.-F., 2007. Sensitivity study of $\mathrm{CO}_{2}$ storage capacity in brine aquifers with closed boundaries: dependence on hydrogeologic properties, Sixth Annual Conference of Carbon Capture and Sequestration: Pittsburgh, PA, USA. 


\section{Figure captions}

Figure 1. Distribution of the Bunter Sandstone Formation (offshore) and Sherwood Sandstone Group (onshore) in Eastern England and the UK sector of the Southern North Sea. The Central Fracture Zone/Dowsing Fault Zone is shown schematically and consists of a number of individual faults.

Figure 2. Seismic section showing periclinal fold with axial faults, formed above a Zechstein salt pillow, UK Southern North Sea (data courtesy of Schlumberger WesternGeco). 1. Top Haisborough Group, 2. Top Bunter Sandstone, 3. Near top Bunter Shale, 4. Top Zechstein Group, 5. Top Rotleigend Group.

Figure 3. Core plug data from Bunter Sandstone in 23 wells from the UKSNS (a) Histogram showing porosity values (b) Porosity and permeability relationship (c) Horizontal and vertical permeability relationship.

Figure 4. Geophysical logs through a typical well through the Triassic succession in the NW part of the UKSNS.

Figure 5. Bunter Sandstone model, thicknesses (metres) denoted by colour shading (a) and depth to top surface denoted by line contours (b). The superimposed pale blue regions delineate the salt walls that cut through the reservoir and the red polygon defines the model boundary. The locations of the $\mathrm{CO}_{2}$ injection point for the base case model runs (IP) and the five observation points (OP1 to 5) are also indicated. The red dot on plot (b) shows the location of the seabed outcrop of the sandstone. The mesh used for modelling is shown in (c) with the active region within the close lateral boundary shaded green.

Figure 6. Pressure data from the UK sector of the Southern North Sea (data courtesy of IHS). See Section 4 of text for explanation.

Figure 7. Reservoir pressure increase (a), reservoir pressure as a percentage of lithostatic pressure (b) in the base case model at 50 years. $\mathrm{CO}_{2}$ saturation in the base case model after 50 years (c) and 3000 years (d). Reservoir pressure changes at the observation points (e) and brine flow rate and cumulative flow from the seabed outcrop (f). 
Figure 8. Comparison of the reservoir pressure distribution (expressed as a percentage of lithostatic) in the base case simulation with (a) and without (b) the seabed outcrop.

Figure 9. Results for the simulation using increased overburden permeability. Reservoir pressure increase (a), reservoir pressure as a percentage of lithostatic pressure (b) in the model at 50 years. $\mathrm{CO}_{2}$ saturation after 50 years (c) and 3000 years (d). Reservoir pressure changes at the observation points (e) and brine flow rate and cumulative flow from the seabed outcrop (f).

Figure 10. Results for the base case simulation parameters using relative permeability data for the Cardium Formation (Bennion \& Bachu 2006), which is compared to the base case Utsira data in plot (d).

Figure 11. Effect of reducing reservoir permeability to $20 \mathrm{mD}$. Reservoir pressure increase (a), reservoir pressure as a percentage of lithostatic pressure (b) in the model at 50 years. $\mathrm{CO}_{2}$ saturation after 50 years (c) and 3000 years (d). Reservoir pressure changes at the observation points (e) and brine flow rate and cumulative brine displacement at the seabed outcrop (f).

Figure 12. Pressure distribution (a) at 50 years and reservoir pressure as a percentage of lithostatic pressure (b) with twelve injection points each injecting $1 \mathrm{Mt}$ per year. The injection points are marked by red circles. $\mathrm{CO}_{2}$ saturation after 50 years is shown at 9c) and after 1580 years at (d). Reservoir pressure changes at the observation points are shown at (e) and brine flow rate and cumulative brine displacement at the seabed outcrop at (f).

Figure 13. Results for models with formation permeabilities of $100 \mathrm{mD}(\mathrm{a}, \mathrm{c}, \mathrm{e})$ and $20 \mathrm{mD}(\mathrm{b}, \mathrm{d}, \mathrm{f})$ with various injection rates at points marked by red circles. The top plots $(\mathrm{a}, \mathrm{b})$ show pressure change at 50 years, the middle plots $(\mathrm{c}, \mathrm{d})$ show pressure as a percentage of lithospheric pressure at 50 years, and the bottom plots (e,f) show flow rates and cumulative flow of brine from the seabed outcrop. 
Tables

Table 1. Mean porosity and permeability data taken from available UKSNS core plug data from 23 wells in the Bunter Sandstone. Ka values represent permeability to air, while Kl are Klinkenberg-corrected liquid permeabilities.

\begin{tabular}{|lccccc|}
\hline & & Horizontal Permeability $(\mathrm{mD})$ & \multicolumn{2}{c|}{ Vertical Permeability $(\mathrm{mD})$} \\
\hline & $\begin{array}{c}\text { Helium } \\
\text { Porosity (\%) }\end{array}$ & $K a$ & $K l$ & $K a$ & $\mathrm{Kl}$ \\
\hline Arithmetic Mean & 19 & 446.31 & 483.22 & 294.32 & 26.08 \\
\hline Geometric Mean & 17.04 & 41.26 & 33.71 & 15.52 & 28 \\
\hline
\end{tabular}

Table 2. Porosity and permeability in UKSNS gas fields with Bunter Sandstone reservoirs (from Bifani 1986; Cooke-Yarborough \& Smith 2003; Ritchie \& Pratsides 1993).

\begin{tabular}{|ccc|}
\hline Field Name & $\begin{array}{c}\text { Typical } \\
\text { porosity }(\%)\end{array}$ & $\begin{array}{c}\text { Typical } \\
\text { permeability }(\mathrm{mD})\end{array}$ \\
\hline Hewett & 21 & 500 \\
\hline Little Dotty & 21 & 350 \\
\hline Esmond & $23-24$ & 87 \\
\hline Caister B & 21 & 100 \\
\hline Forbes & $15-25$ & - \\
\hline Gordon & $14-21$ & - \\
\hline
\end{tabular}

Table 3. Brine salinity and density in Bunter Sandstone gas fields in the UKSNS (from Warren \& Smalley 1994, Ritchie \& Pratsides 1993).

\begin{tabular}{|lcc|}
\hline Field Name & Brine salinity $(\mathrm{ppm})$ & Brine density $\left(\mathrm{g} \mathrm{cm}^{-3}\right)$ \\
\hline Esmond* & 294000 & 1.211 \\
\hline Forbes* & 303000 & $1.220^{\dagger}$ \\
\hline Orwell & 180000 & 1.119 \\
\hline Caister B & 250000 & $1.174^{\dagger}$ \\
\hline$*$ The formation water in the Esmond complex as a whole is quoted elsewhere as salt saturated at reservoir conditions with salinity of $130000-205000 \mathrm{ppm} \mathrm{NaCl}$
\end{tabular}


Table 4. Parameters for the base case model.

\begin{tabular}{|ll|}
\hline Reservoir permeability $(k)$ & $10^{-13} \mathrm{~m}^{2}(100 \mathrm{mD})$ \\
\hline Ratio of vertical to horizontal permeability $\left(k_{v} / k_{h}\right)$ & 1 \\
\hline Reservoir porosity $(\theta)$ & $20 \%$ \\
\hline Reservoir pore volume $\left(\mathrm{V}_{\mathrm{p}}\right)$ & $350 \mathrm{~km}^{3}$ \\
\hline Pore compressibility $\left(\alpha_{\mathrm{p}}\right)$ & $4.5 \times 10^{-10} \mathrm{~Pa}^{-1}$ \\
\hline Brine salinity & $130,000 \mathrm{ppm} \mathrm{NaCl}$ \\
\hline Thermal gradient $(\mathrm{dT} / \mathrm{dz})$ & \begin{tabular}{l}
$35^{\circ} \mathrm{C} / \mathrm{km}$ \\
\hline Boundary conditions
\end{tabular} \\
$\begin{array}{l}\text { The lateral boundaries and underlying boundaries are } \\
\text { impermeable. } 500 \mathrm{~m} \text { of caprock with a permeability of } \\
10^{-19} \mathrm{~m}^{2} \text { overlies the reservoir. }\end{array}$ \\
\hline
\end{tabular}





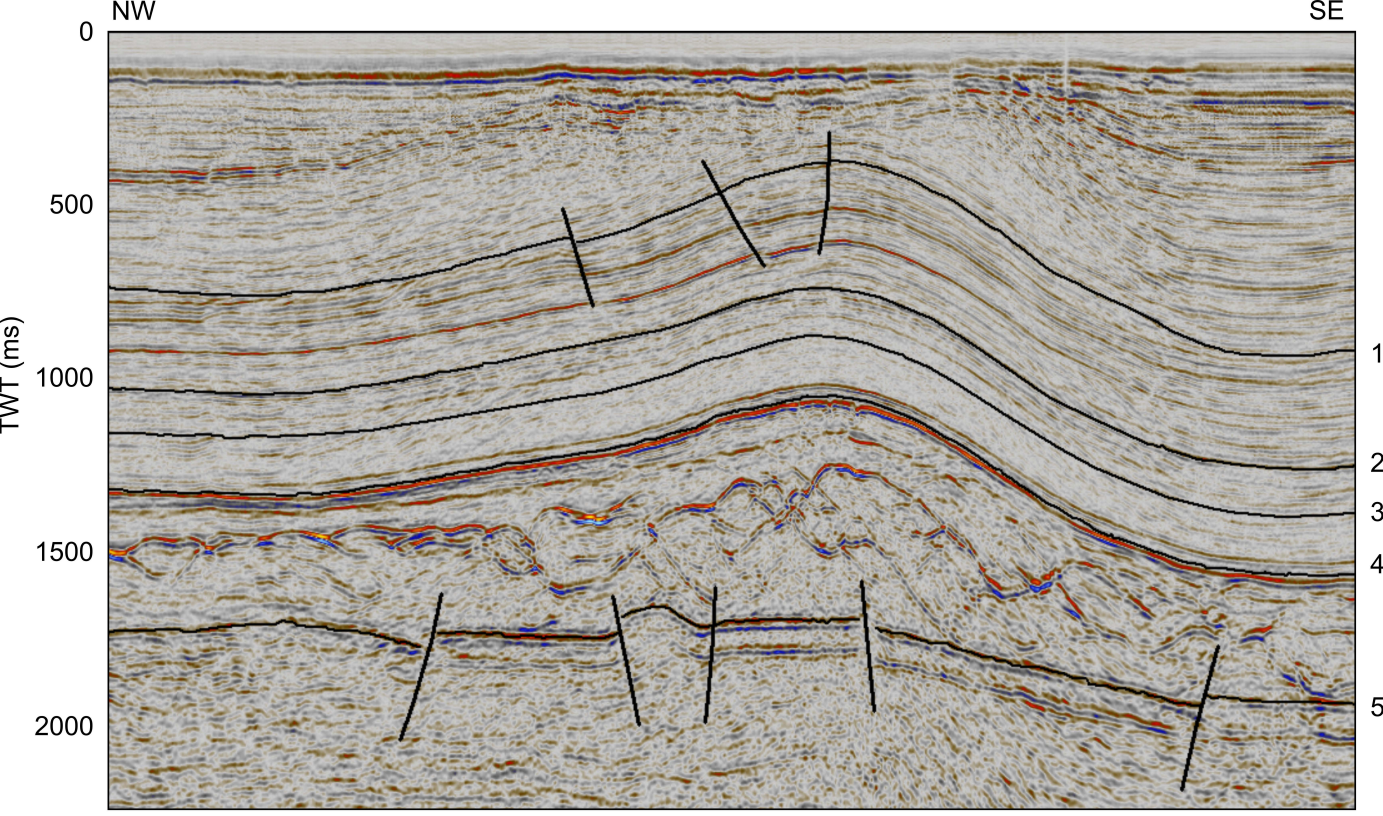

$$
5 \mathrm{~km}
$$



6100000

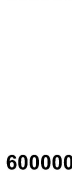

60000

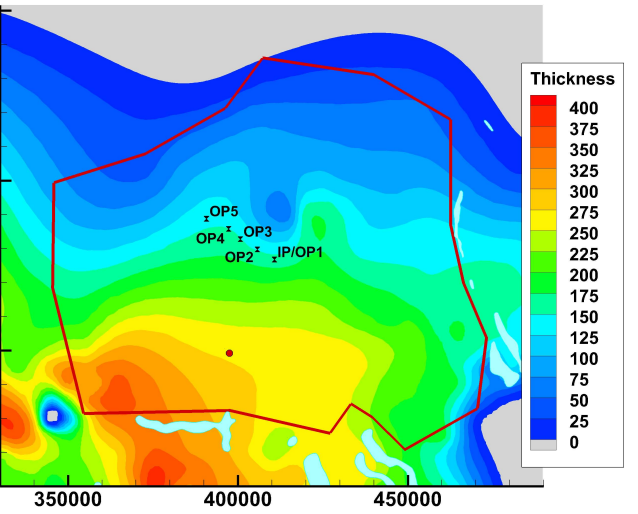

(c)

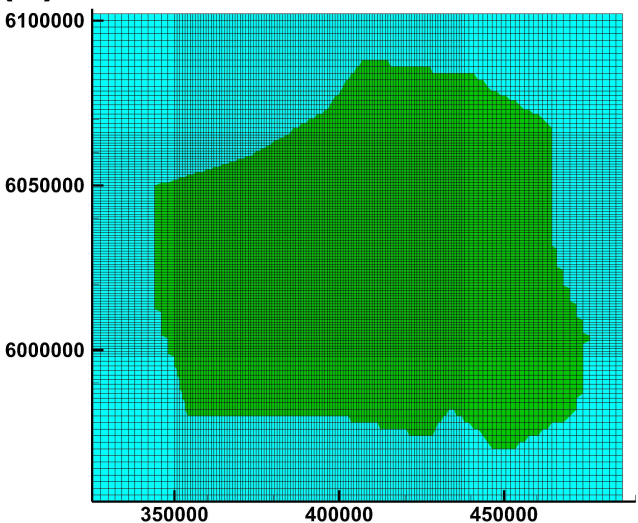

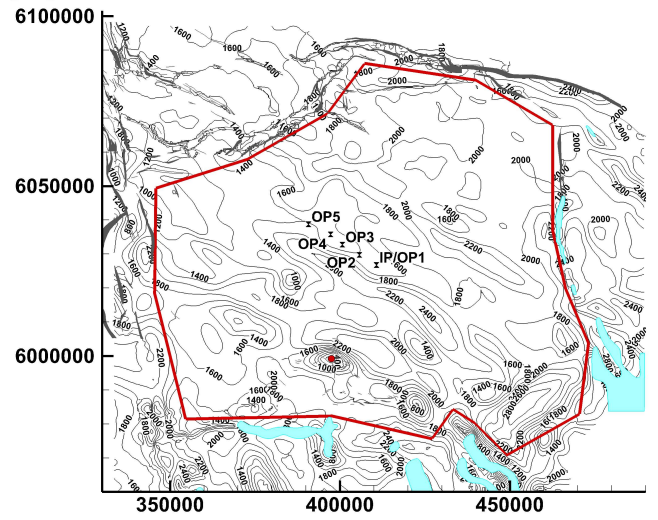


(a) $50.0 \mathrm{yr}$

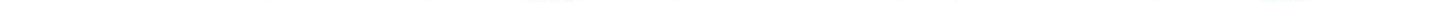

(b) $50.0 \mathrm{yr}$ 
(a) $50.0 \mathrm{yr}$ (e)

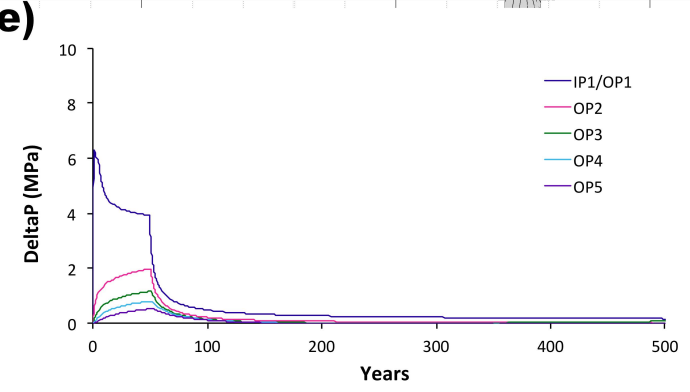

\section{(c) $50.0 \mathrm{yr}$}

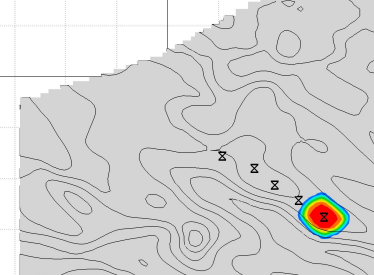

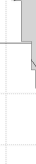

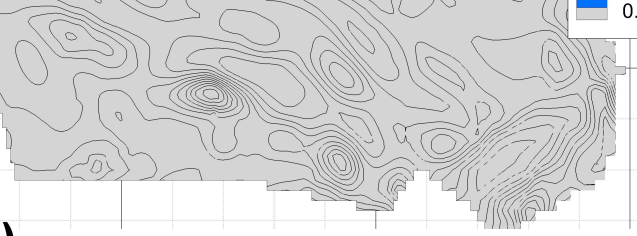

(b) $50.0 \mathrm{yr}$

LithP\%

80

75
70

65

60

55

50

40

(d) $3000.0 \mathrm{yr}$

(f)

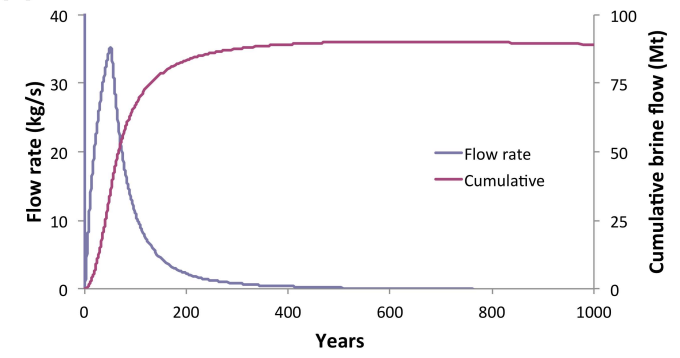


(a) $50.0 \mathrm{yr}$

(C) $50.0 \mathrm{yr}$

(e)

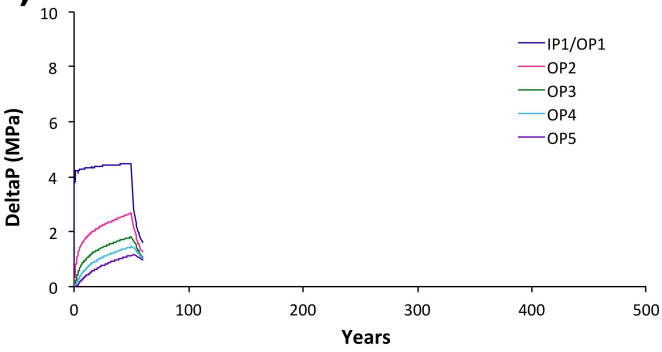

(b) $50.0 \mathrm{yr}$

(d)

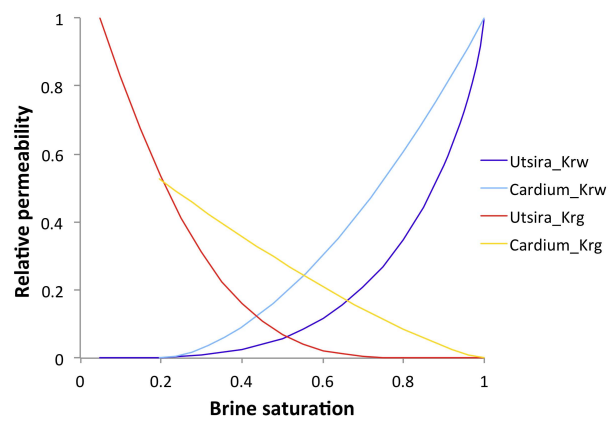

(f)

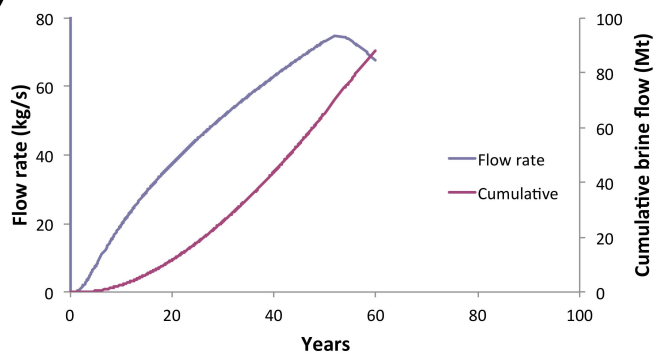


(a) $50.0 \mathrm{yr}$

(c) $50.0 \mathrm{yr}$

(e)

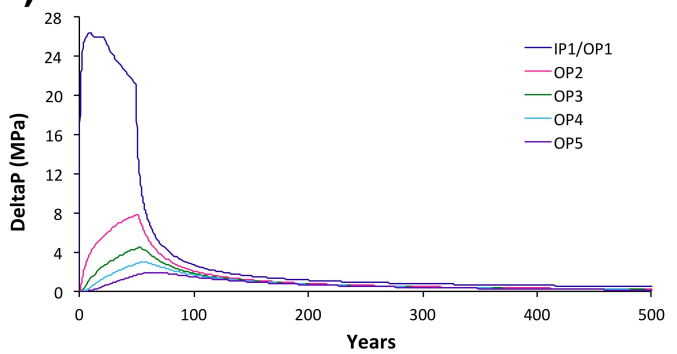

(b) $50.0 \mathrm{yr}$

(d) $3000.0 \mathrm{yr}$

(f)

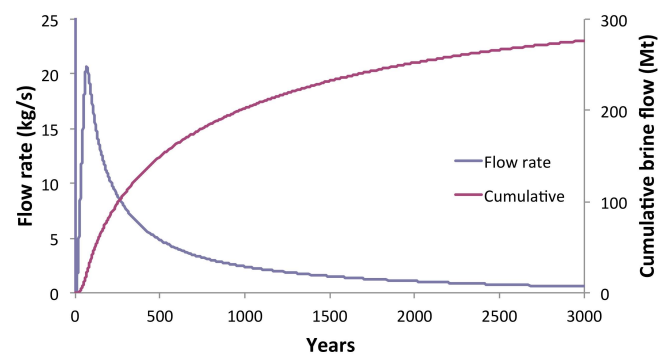


(b) $50.0 \mathrm{yr}$

(f)

\section{(d) $50.0 \mathrm{yr}$}

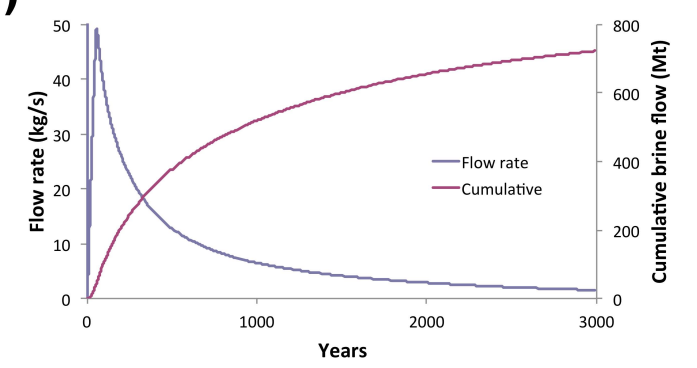

LithP\%

$80-$

75

65

60

55

50

45
40 (c) $50.0 \mathrm{yr}$ (e)

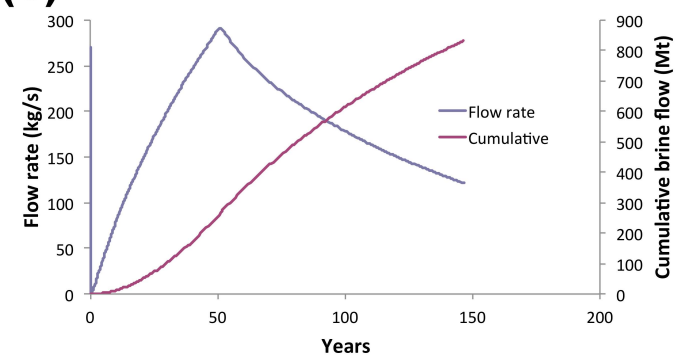

$00 \frac{3}{3}$

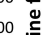

을

00 空

है

00 క

Years (a) $50.0 \mathrm{yr}$
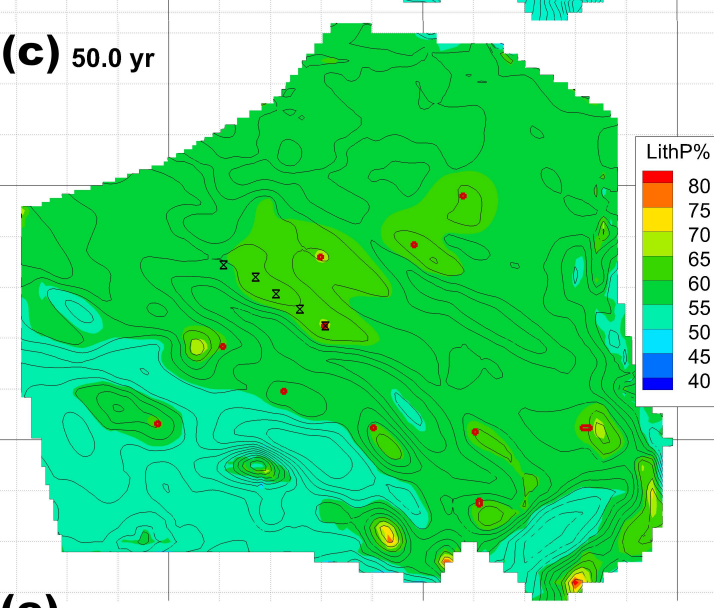

产
DeltaP(MPa)

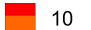

10

8

7

6

5
4

3

2
1

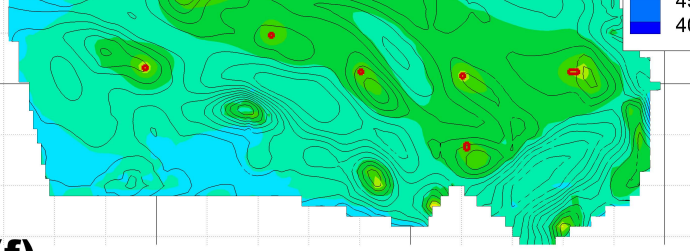

